\title{
The Impact of the Seat of Arbitration on Judicial-Interference: Do Sections 67, 68 and 69 of the English Arbitration Act 1996 regarding Challenges of Awards Make London An Attractive Hub?
}

\author{
"Tahkim Yerinin, Müdahale Etmeme İlkesi Üzerindeki Rolü: Hakem Kararlarına \\ Karşı Kanun Yoluna İlişkin 1996 tarihli İngiliz Tahkim Kanunu 67, 68 ve 69. Bölümler \\ Londra'nın Cazip Bir Tahkim Merkezi Olmasını Sağlıyor Mu?"
}

\section{Fulya Teomete Yalabık* ${ }^{*}$}

\begin{abstract}
There are various determinants that induce London to be the favourable seat. In this regard, the grounds for challenging an award have some severe implications on determining London as the arbitral seat. ${ }^{1}$

Arbitrations with a London seat are exercised under the 'supervisory jurisdiction' ${ }^{2}$ of the English courts and the Arbitration Act 1996 (AA 1996). ${ }^{3}$ That is to say, any challenge to an interim or final award made by the arbitrators may be fulfilled in the courts of the location chosen as the arbitral seat.

The consensual nature of international arbitration depends on certain core principles such as party autonomy, judicial nonintervention and finality of the arbitral awards. Nonetheless, the binding aspect of the arbitral award and its enforceability akin to that of final judgements of national courts necessitate some "balanced" degree of judicial supervision. ${ }^{4}$
\end{abstract}

\section{Keywords}

English Arbitration Act, Arbitral seat, challenging an award, judicial non-intervention, finality

\section{Öz}

Londra'yı tercih edilen bir tahkim yeri haline getiren çeşitli belirleyiciler söz konusudur. Bu bağlamda, hakem kararlarına karşı kanun yoluna başvuru sebeplerinin, Londra'nın tahkim yeri olarak belirlenmesinde bazı önemli etkileri vardır.

Tahkim yerinin Londra olarak belirlendiği tahkimler İngiliz mahkemelerinin 'denetleyici yetkisi' ve 1996 tarihli Tahkim Kanunu'nun kapsamında icra edilmektedir. Yani, hakemlerin ara veya nihai kararlarına yönelik kanun yolu başvurularında tahkim yeri olarak belirlenen yer mahkemeleri yetkili olmaktadır.

Uluslararası tahkimin rızaya dayalı doğası, taraf özerkliği, yargıya müdahale etmeme ve hakem kararlarının kesinliği gibi bazı temel ilkelere bağlıdır. Bununla birlikte, hakem kararının bağlayıcı yönü ve ulusal mahkemelerin nihai kararlarına benzer şekilde icra edilmeleri, "dengeli" bir şekilde uygulanacak bir yargı denetiminin varlığını gerektirmektedir.

\section{Anahtar Kelimeler}

İngiliz Tahkim Kanunu, Tahkim yeri, hakem kararına karşı kanun yoluna başvuru, yargılamaya müdahale etmeme ilkesi, kesinlik

\footnotetext{
* Corresponding Author: Fulya Teomete Yalabık (Dr.) Lawyer, London, United Kingdom. E-mail: fulya.teomete-yalabik@city.ac.uk ORCID: 0000-0002-1684-5898

To cite this article: Teomete Yalabık, F, 'The Impact of the Seat of Arbitration on Judicial-Interference: Do Sections 67,68 and 69 of the English Arbitration Act 1996 regarding Challenges of Awards Make London An Attractive Hub?", (2021) 70 Annales de la Faculté de Droit d'Istanbul 253. https://doi.org/10.26650/annales.2021.70.0009

1 Susan Blake, Julie Browne, Stuart Sime, A Practical Approach to Alternative Dispute Resolution (5 $5^{\text {th }}$ edn, OUP 2018 ) 484.

2 C v D [2008] Bus LR 843.

3 Blake, Browne, Sime (n 1) 483

4 Hossein Abedian, 'Judicial Review of Arbitral Awards in International Arbitration-A Case for an Efficient System of Judicial Review' (2011) 28 (6) Journal of International Arbitration 533.
} 


\section{The Impact of the Seat of Arbitration on Judicial-Interference: Do Sections 67, 68 and 69 of the English Arbitration Act 1996 regarding Challenges of Awards Make London An Attractive Hub?}

\section{Introduction}

The seat of an arbitration is the juridical link of the arbitration process, in other words, "the jurisdiction in which an arbitration takes place legally." It differs from the venue, which correlates to the geographical location in which the arbitration proceedings occur. ${ }^{6}$ Despite the distinctness, since the seat and venue are tied closely, when there is no choice about the seat in the arbitration agreement, the venue becomes an important element in designating the jurisdiction of the applicable court. ${ }^{7}$

Arbitrations with a London seat are exercised under the 'supervisory jurisdiction'8 of the English courts and the Arbitration Act 1996 (AA 1996). ${ }^{9}$ That is to say, any challenge to an interim or final award made by the arbitrators may be fulfilled in the courts of the location chosen as the arbitral seat. ${ }^{10}$

Currently, London performs the most preferred seat role for international arbitration worldwide. ${ }^{11}$ London's reputation derives from the foundation of the AA 1996, which is modern, arbitration-friendly legislation. ${ }^{12}$ Thereby, there are various determinants that conduce London to be a pre-eminent hub. This article identifies the characteristics of London's attractiveness as the seat of arbitration in general. Then, the article particularly focuses on the importance and effect of the grounds on which

5 Simon Greenberg, Christopher Kee, Romesh Weeramantry, International Commercial Arbitration: An Asia-Pacific Perspective (CUP 2011) 54. There must be a country whose duty is to supervise, or decide what control there should be over an arbitration, Braes of Doune Wind Farm (Scotland) Ltd v Alfred McAlpine Business Services Ltd [2008] 2 All ER (Comm) 493 .

6 Greenberg, Kee, Weeramantry (n 5) 54.

7 Phillip Capper, Dipen Sabharwal, Clare Connellan, 'When is the 'Venue' of an Arbitration its 'Seat'?, Kluwer Arbitration Blog (November 25, 2009), <http://arbitrationblog.kluwerarbitration.com/2009/11/25/when-is-the-venue-of-anarbitration-its-seat/> (accessed 15.07.2021); Gonzalo Vial and Francisco Blavi, 'New Ideas for the Old Expectation of Becoming an Attractive Arbitral Seat' (2016) 25 Transnational Law \& Contemporary Problems 279, 281; Shashoua and ors $v$ Sharma [2009] EWHC 957 (Comm).

$8 \quad C v D[2008]$ Bus LR 843.

9 Blake, Browne, Sime (n 1) 483.

10 ibid 484 .

112018 Queen Mary University of London, White \& Case International Arbitration Survey: The Evolution of International Arbitration, <http://www.arbitration.qmul.ac.uk/media/arbitration/docs/2018-International-Arbitration-Survey---TheEvolution-of-International-Arbitration-(2).PDF> 9; see also 2021 International Arbitration Survey: Adapting arbitration to a changing world, http://www.arbitration.qmul.ac.uk/media/arbitration/docs/LON0320037-QMUL-InternationalArbitration-Survey-2021_19 WEB.pdf (accessed 15.07.2021). According to the 2021 Survey, London once again is selected as the most preferred arbitral seat. However, London was selected by $64 \%$ of respondents in 2018 , it dropped to $54 \%$ in this new Survey. One of the significant reasons for this drop may be because London was not selected as the most preferred seat for respondents in Asia-Pacific. Asia-Pacific, both Singapore and Hong Kong surpassed London by a margin of $20 \%$. This shows that regional seats such as Singapore and Hong Kong are growing in reputation and popularity and upset the balances in the arbitration map. Nevertheless, this growing success of Asia-Pacific has not had a strong effect of defeating London's robust reputation as the most preferred seat.

12 Vial and Blavi (n 7) 290; Julian Lew, 'London' in Michael Ostrove, Cladia Salomon, Bette Shifman (eds), Choice of Venue in International Arbitration (OUP 2014) 242. 
an award can be challenged under the AA 1996. In this regard, the effects of AA 1996 article 67, 68 and 69on the attractiveness of London as the seat are analysed.

Following a brief introduction, in the first chapter, the importance of the arbitral seat is examined. Secondly, the reasons why London is chosen as a preferred hub are discussed. Lastly, the effects of grounds of challenging an award in the selection of London as the seat are elaborated.

\section{The Importance of the Arbitral Seat}

The arbitral seat has essential legal and practical consequences that can substantially change the progress and result of the arbitral process for the parties in international arbitration. ${ }^{13}$ The choice of the seat is critical for the parties ${ }^{14}$ primarily because it decides the lex arbitri, or the law of the place where the arbitration is to occur, and this grants the related courts supervisory jurisdiction over the proceedings. ${ }^{15}$

The seat will also determine the extent to which the national court will promote or interfere in the arbitration procedure. ${ }^{16}$ Some countries have legislations that restrain party autonomy concerning the procedure and recognize the courts' intervention in the arbitral process. On the other hand, some other countries have rather permissive national laws that tolerate the parties' extensive procedural autonomy and limit intervention by the courts. It is an indicator of the effective reinforcement for the arbitration procedure in relevant countries. ${ }^{17}$

In principle, the courts of the arbitral seat are empowered to receive and decide upon appeals of arbitration awards so that the extent to which an arbitral award may be challenged will be decided in accordance with the arbitral seat. Besides this, the ambit of the entitled parties to apply for the judicial review will be determined by the selection of jurisdiction. These aspects will guide the degree to which an award is presumed to be final. ${ }^{18}$

The degree of the limitation on the grounds of challenging an award may change from country to country, and also in some countries the challenge of the award is

13 Gary B Born, International Arbitration and Forum Selection Agreements: Drafting and Enforcing, (3th edn, Wolters Kluwer International 2010) 2052; Peter Turner and Reza Mohtashami, A Guide to LCIA Arbitration Rules (OUP 2009) 114-115.

14 Georgios Petrochilos, Procedural Law in International Arbitration (OUP 2004) chapter 3.

15 Capper Sabharwal, Connellan (n 7); David Hesse, 'The Seat of Arbitration is Important. It's That Simple.', Kluwer Arbitration Blog, (June 10, 2018), <http://arbitrationblog.kluwerarbitration.com/2018/06/10/seat-arbitration-importantsimple/> (accessed 15.07.2021); Jeffrey Waincymer, Procedure and Evidence in International Arbitration, (Kluwer Law International 2012) 170; Hakeem Seriki, 'Enforcing Annulled Arbitral Awards: Can the Unruly Horse Be Tamed?' (2018) 8 Journal of Business Law 679, 683.

16 Jonathan Hill, 'Determining the Seat of an International Arbitration: Party Autonomy and the Interpretation of Arbitration Agreements' (2014) 63 Int Comp Law Q 517.

17 ibid.

18 ibid. 
provided on errors of law. ${ }^{19}$ In sum, the grounds for annulling arbitral awards are established in the national arbitration laws of the seat ${ }^{20}$, and the degree and extent to which judicial review would be available to parties will be based on those same laws ${ }^{21}$ and the national court's approach towards international arbitration. Moreover, national courts could influence the quickness and costs of the proceedings because they might be involved at a certain level in points like the selection, challenge, removal and appointment of arbitrators. ${ }^{22}$

The recognition and enforcement of an arbitral award will also be affected by the choice of the seat. The seat will be directly significant in identifying whether an award is a 'New York Convention award' or not, which will necessarily determine whether an award has mutual recognition and enforcement in other countries. ${ }^{23}$

Besides, the selection of the seat will have an impact on the accessibility of the venue to the parties of the arbitration and the infrastructure providing the support to conduct the arbitration process easily and properly.

The consequences arising from the choice of the arbitral seat transform the decision into one of the most crucial elements of any international agreement, ${ }^{24}$ pressuring the parties to designate the arbitral seat attentively. ${ }^{25}$ Selecting a specific seat designates matters that probably alter the outcome of arbitration: the recognition and enforcement of arbitral awards, the courts with supervisory jurisdiction over the arbitration, and the costs of the procedure. ${ }^{26}$ In other words, the arbitral seat directly influences the prospect of an effective arbitration process and outcome. A poor choice could produce unenforceable awards; an extensive review of international arbitral awards is more likely invalidated; court's undue interference costs further expenditure and time. For these reasons, seat selection is essential and determinative of the outcome..$^{27}$

According to the 2018 Survey on International Arbitration by the Queen Mary University of London, the most crucial considerations for preferred seats were their 'general reputation and recognition', the 'neutrality and impartiality of the local legal

19 Gonzalo Vial, 'Influence of the Arbitral Seat in the Outcome of an International Commercial Arbitration' (2017) 50(2) International Lawyer 329, 330; William Kirtley, The Importance of the Seat of Arbitration, International Arbitration Attorney Network (February 8, 2016), <https://www.international-arbitration-attorney.com/importance-seat-arbitration/> (accessed 15.07.2021).

20 Teresa Giovannini, 'The Making and Enforcement of Arbitral Award: What are the Grounds on Which Awards Are Most Often Set Aside?' (2001) 1 Business Law International 115.

21 Vial (n 19) 331.

22 ibid.

23 Turner and Mohtashami (n 13) 114-115.

24 Born (n 13) 64.

25 Capper, Sabharwal, Connellan (n 7); Vial (n 19) 329.

26 Vial (n 19) 332.

27 ibid 332-3. 
system', 'the national arbitration laws', 'the track record of enforcing agreements to arbitrate' and 'arbitral awards'. ${ }^{28}$ The last three arguments indicate that arbitration users will favour a particular seat if the legal mechanism furnishes them with sufficient guarantees. For example, objective and impartial treatment by courts and a smooth recourse to arbitration are regarded as satisfactory. ${ }^{29}$

In parallel with the 2018 Survey, in the recent 2021 Survey on International arbitration, the most important considerations were 'greater support for arbitration by local courts and judiciary', 'increased neutrality and impartiality of the local legal system' and 'better track record of enforcing agreements to arbitrate and arbitral awards'. ${ }^{30}$ It can be deduced that the other preferred choices were influenced by the unprecedented situations that Covid 19 has caused. These are 'ability to enforce decisions of emergency arbitrators or interim measures ordered by arbitral tribunals', 'ability for local courts to deal remotely with arbitration related matters' and 'allowing awards to be signed electronically'. ${ }^{31}$

\section{The Reasons Behind Why London is Chosen As The Seat?}

Becoming a favourable international arbitration hub amounts to an extremely competitive task. There are several components that are determinative on attractive seats. ${ }^{32}$ For example, a supportive legal system for arbitration, a neutral approach from national courts, competent practitioners, and political and economic permanency are principal characteristics of prominent centres like London for international arbitration. ${ }^{33}$

\section{A. Contracting State Under the New York Convention}

In order to protect the efficiency of the arbitral proceedings, it is a sensitive matter to enable judicial review of arbitral awards. ${ }^{34}$ Since parties mostly prefer arbitration to avert unwanted aspects of litigation, ${ }^{35}$ one of the main purposes of arbitration is not to be frustrated by comprehensive judicial review of awards. On

\footnotetext{
282018 Queen Mary University of London, White \& Case International Arbitration Survey (n 11) 9.

29 ibid 10

302021 International Arbitration Survey (n 11).

312021 International Arbitration Survey (n 11).

32 Vial and Blavi (n 7) 307. In addition, it is worth to mention that 'The London Principles' developed by a working group for the Chartered Institute of Arbitrators centenary, comprise ten elements list to provide a balanced and independent basis for the assessment of existing seats and to encourage the development of new seats, Janet Walker, 'The London Principles and Their Impact on Law Reform' (2018) 84 (2) Arbitration 174, 178. When these principles are considered, it can be seen that London as a leading arbitral seat complies all of these principles.

33 Vial and Blavi (n 7) 307-308.

34 Jessica L Gelander, 'Judicial Review of International Arbitral Awards: Preserving Independence in International Commercial Arbitrations' (1997) 80 Marquette Law Review 625, 626

35 ibid 641.
} 
the other hand, absolute autonomy from the forum is not conclusively favourable. ${ }^{36}$ A complete lack of judicial control might threaten the arbitral process because "a forum with no system of review is more susceptible to abuse." ${ }^{37}$ To stabilize these abovementioned interests, the New York Convention formulates limited grounds for declining to recognize and enforce international arbitration awards ${ }^{38}$ In this regard, it is suggested that the arbitral seat must always be a state that has abided by the New York Convention because the location where the award is made has considerable legal effects for its enforceability. ${ }^{39}$

The New York Convention, to which the 167 other countries are signatories, became effective in the United Kingdom (UK) in 1975. Being a party to the New York Convention also enhances London's attractiveness. However, considering all 167 countries, which are also signatories to the New York Convention, applying the same rules while enforcing a foreign arbitral award rendered anywhere else globally, the UK is not in the minority to be favoured by the New York Convention today. Brexit has not negatively affected the enforcement of arbitral awards and the UK remains a signatory to the New York Convention.

It should also be considered that there is a right of appeal before the courts on questions of English law unless the parties otherwise agree. ${ }^{40}$ Furthermore, an award can be challenged on the ground of deficiency of substantive jurisdiction or a serious irregularity affecting the tribunal..$^{41}$ These challenges and their impact on London's appeal as the arbitral seat will be examined in more detail in the third section below.

\section{B. The National Court's Attitude Towards Arbitration}

The national court's attitude towards international arbitration is important for choosing an arbitral seat. Domestic courts should interfere as little as possible in the arbitral proceedings but should be available at the same time to assist the arbitrators whenever required. The most preferred place for arbitration is one where domestic courts assure the unity of the procedure but do not unnecessarily and unjustly interfere with honest mistakes of law or fact. ${ }^{42}$ Such an approach safeguards the parties' authority to adapt the arbitration to their particular expectations and necessities. Accordingly, the London practice trends to show a pro-arbitration attitude ${ }^{43}$ The AA 1996 is a crucial pillar of the support of arbitration. In that regard, the English courts

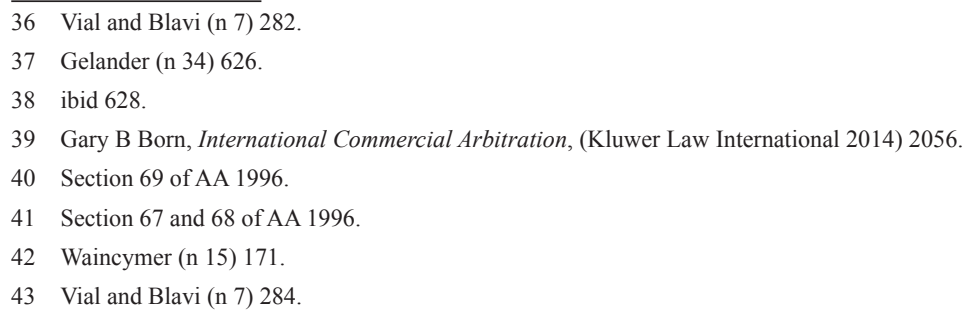


are authorised to make orders in aid of the arbitration process of a tribunal. Such discretion may be vital to the hassle-free conduct of an arbitration. However, the courts will not exceed their authority and intervene in proceedings, and they should be very attentive to leave the convenient points to the tribunal. ${ }^{44}$ The national court's support role is for not only before and during the arbitration but also after the award. Whilst challenging an award, the AA 1996 gives national courts three precise grounds and expects that these grounds are not used unduly. The national court's attitude towards challenging an award is discussed in detail in the third part of this article.

\section{Material Conditions and Location}

It is decisive for the parties to prefer a seat surrounded by institutions and resources of high standards to encourage the arbitration process and assure that it proceeds effectively. One notable advantage of arbitrating in London is the convenience of experts to function as arbitrators specialised in resolving a wide variety of commercial disputes. $^{45}$

In addition, third-party funding has been encouraged in arbitration by the English courts. In Essar Oilfields Services Ltd v Norscot Rig Management PVT Ltd ${ }^{46}$, the Court decided that third-party funding exists under the scope of other costs according to section 59(1)(c) of the AA 1996. That is why the Court concluded that it was part of the authority of a tribunal established under the ICC Rules to award recovery of the additional costs to be paid to a third-party funder. Essentially, this implies that arbitration is more tempting than litigation to parties in cases where thirdparty funding may be required and presumably attracts more third-party funders to London. ${ }^{47}$

A particular seat may become broadly used if it is conveniently located and accessible. ${ }^{48} \mathrm{~A}$ well-connected city has extensive opportunities to offer the international arbitration community. ${ }^{49}$ London is a suitable hub that allows the arbitration's parties, representatives, and arbitrators to convene in the same place for hearings and other procedural matters. The parties should consider all relevant circumstances, such as geographical location, the capacity of suitable accommodations, the standard of the arbitration facilities, and the quality and variety of transportation and communication

44 HC Trading Malta Ltd v Tradeland Commodities SL [2016] EWHC 1279 (Comm).

45 Srishti Jain, 'UK: Why London Continues to be an Attractive Seat for International Arbitration Post-Brexit' Mondaq, 23 June 2021, <https://www.mondaq.com/uk/arbitration-dispute-resolution/1082072/why-london-continues-to-be-anattractive-seat-for-international-arbitration-post-brexit> (accessed 15.07.2021).

46 [2016] EWHC 2361 (Comm).

47 Duncan Speller and Mark Feldner, 'The International Arbitration Review: United Kingdom-England and Wales', edition 12, (July 2021) <https://thelawreviews.co.uk/title/the-international-arbitration-review/united-kingdom-england--wales > accessed 15.07.2021).

48 Pierre A Karrer, Introduction to International Arbitration Practice (Kluwer Law International 2014) 16.

49 Vial and Blavi (n 7) 287. 
systems. ${ }^{50}$ Moreover, amenities that are not directly relevant to the proceedings, such as restaurants or shopping centres, could also be an effective factor for a forum. ${ }^{51}$

In light of this, London confirms that it is a favourable arbitration hub regarding its material conditions and location.

\section{The Neutrality of the Place}

The neutrality of the arbitral seat can be seen as the union of practical and juridical parts. ${ }^{52}$ Whilst the practical feature indicates a typical concern for protecting the parties' genuine equality, the juridical part emphasizes the impartiality of the arbitral tribunal's decision in a case where domestic courts actively supervise and intervene in the decisions of the arbitral tribunal. ${ }^{53}$ According to the survey results, London is a preferred hub in international disputes particularly regarding the impartiality and neutrality of the English legal system. ${ }^{54}$

\section{E. Political and Economic Stability}

Political and economic environments have significant importance on parties' preference for an arbitral seat. ${ }^{55}$ Parties generally choose politically and economically stable countries as the seat of arbitration because these countries enable better assurances of protection and trust.

London is an enviable arbitral hub for its political and economic stability. Nevertheless, Brexit has some potential effects on this stability and causes some discussions about London's attractiveness. On January 31, 2020, the UK ceased to be a European Union (EU) Member State, but its practical impact was not seen until the end of the transition period on 31 December 2020. With the provisional application of a trade and cooperation agreement between the UK and the EU on 1 January 2021, the parties' relationship has essentially undergone a change.

The impact of Brexit on the London legal market still preserves its popularity. According to some views, the unpredictability caused by Brexit threatens London's prominence as a desirable seat within Europe. ${ }^{56}$ On the other hand, it is a fact that the

50 Alexander J Belohlavek, 'Seat of Arbitration and Supporting and Supervising Function of Courts' in Alexander Belohlavek, Nadezda Rozehnalova (eds), Interaction of Arbitration and Courts, Czech Yearbook of Arbitration, vol 5 (2015, Juris) 35.

51 Vial and Blavi (n 7) 285.

52 ibid.

53 Pierre Lalive, 'On the Neutrality of the Arbitrator and of the Place of Arbitration', Swiss Essays on International Arbitration (1984), 30, 31, <https://www.lalive.law/data/publications/43_-_On_the_Neutrality_of_the_Arbitrator_and_of_the_Place_ of_Arbitration_Recueil_de_travaux_suisses_sur_l'arbitrage_international.pdf $>$ (accessed 15.07.2021).

542018 Queen Mary University of London, White \& Case International Arbitration Survey (n 11) 11; 2021 International Arbitration Survey (n 11) 8.

55 Vial and Blavi (n 7) 286.

56 Michael Mcllwrath, 'An Unamicable Separation: Brexit Consequences for London as a Premier Seat of International Dispute Resolution in Europe' (2016) 33 (7) Journal of International Arbitration 451, 454. 
UK continues to be a signatory to the New York Convention. Whereas there are still concerns about to what extent an English judgment will continue to be enforceable in other European Union (EU) Member States, an arbitration award will maintain use of the current enforcement system. ${ }^{57}$ Additionally, Brexit has allowed English courts more independence to apply for anti-suit injunctions to shield the robustness of an arbitration agreement to arbitrate seats in London. Before Brexit, anti-suit injunctions could not be issued to prevent parties from pursuing any court proceedings in the other EU Member States. ${ }^{58}$ After the Brexit, in case of breach of arbitration agreements, issuing anti-suit injunctions by the English courts was more straightforward.

Despite Brexit, England and Wales is preserving its primacy and is still maintaining one of the most favourite seats for international arbitration. ${ }^{59}$ This is because the sophisticated attractions of England and Wales as a seat depend not only on the strong infrastructure of the AA 1996 but also on 'judicial willingness' to commit the governing guidelines that established the Act. ${ }^{60}$ According to the arbitration community, Brexit has not had and will not have a considerable influence on the very qualified and independent English judiciary that has substantial accomplishments in multifaceted international arbitration. ${ }^{61}$ As stated in the Queen Mary Survey 2018, ${ }^{62}$ $55 \%$ of the respondents believed that Brexit would have no influence on the preference of London as a seat. They anticipated that its 'formal legal structure' would probably remain unaffected and maintain to support arbitration. It can be stated that after a close observation of the after Brexit implications in the UK, no negative impact has been monitored so far by the UK's withdrawal from the European Union. ${ }^{63}$ In line with the 2021 Queen Mary Arbitration Survey, London's continued popularity as a seat, as was predicted by the majority of the respondents in the 2018 survey, has not been significantly impacted. ${ }^{64}$ London maintains its reputation as a reliable seat of choice.

\section{F. Development of Jurisprudence}

Places like London with a long-standing culture of arbitration tend to have a wider jurisprudential advancement of international arbitration questions. ${ }^{65}$ Such an advanced practice experience may give the parties certainty about the attitude of

\footnotetext{
57 Speller and Feldner (n 47).

58 Allianz SpA and Others $v$ West Tankers Inc [2009] EUECJ C-185/07.

592018 Queen Mary University of London, White \& Case International Arbitration Survey (n 11) 11-12; 2021 International Arbitration Survey (n 11) 6.

60 Speller and Feldner (n 47).

61 ibid.

622018 Queen Mary University of London, White \& Case International Arbitration Survey (n 11) 11-12.

63 Justin Williams, Hamish Lal, Richard Hornshaw, 'Arbitration Procedures and Practice in the UK (England and Wales): Overview' $<$ https://uk.practicallaw.thomsonreuters.com/4-502-1378?transitiontype $=$ default\&contextdata $=(\mathrm{sc}$. default)\&firstpage=true $>$ (accessed 15.07.2021).

642021 International Arbitration Survey (n 11).

65 Vial and Blavi (n 7) 287.
} 
domestic courts in various stages of the arbitration process ${ }^{66}$, for example, the national court's non-interventionist approach for challenging arbitral awards. Recent case law proves the fact that the English courts are supportive of international arbitration. Accordingly, the court will only intervene when it is assured that the applicant has exhausted all available arbitral processes. For example, the court will not grant interim relief in cases where the parties can submit such issues to an emergency arbitrator with jurisdiction to order urgent relief. ${ }^{67}$

\section{The Effect of Grounds of Challenging An Award in the Selection of London As The Seat}

\section{A. In General}

One of the distinctive aspects of arbitration as an alternative dispute resolution process is the limited opportunity for challenging arbitral awards. ${ }^{68}$ The AA 1996 specifically included the doctrine of competence-competence into English arbitration law so that competence of an arbitration tribunal to determine and rule on its own jurisdiction in a final and binding way is recognized. However, in some situations mentioned below (in part B), the arbitral tribunal's decision may be dependent on the review by domestic courts, which might necessitate a full re-hearing of the jurisdictional issue.

The AA 1996 is grounded on three prevailing fundamentals provided in section 1. Fairness; 2-Party autonomy; and 3-The restriction of judicial intervention. ${ }^{69}$ AA 1996 is projected to encourage the arbitration proceeding and decreases judicial intervention throughout the arbitration process. ${ }^{70}$ In this regard, the courts have a tendency to build a high barrier on parties willing to challenge arbitration awards ${ }^{71}$ by making challenges only available in severe cases. In such cases where the tribunal misjudges in the conduct of the arbitral process, the lawfulness of the award requires correction. $^{72}$

Unofficial statistics out of the arbitration claims from the Commercial Court between 1996 and 2007 signify that London has progressively transformed into a

66 ibid.

67 Gerald Metals SA v The Trustees of the Timis Trust and others [2016] EWHC 2327.

68 James Carter and Camilla Macpherson, 'Arbitral Awards-Challenging to Challenge' (2016) 19 (4) International Arbitration Law Review 89.

69 AA 1996 Section 1(a), (b), (c), <https://www.legislation.gov.uk/ukpga/1996/23/contents> (accessed 11 May 2019).

70 Itochu Corporation v Johann MK Blumenthal GMBH \& Co KG \&Anr [2012] EWCA Civ 996.

71 Bandwidth Shipping Corporation Intaari (the 'Magdelena Oldendorff') [2007] EWCA Civ 998, [2008] 1 All ER (Comm) 1015, [2008] 1 Lloyd's Rep 7.

72 DAC Report, paras 284-287, The 1996 DAC Report on the English Arbitration Bill: The Last Part, (1999) 15(4) Arbitration International 413; La Société pour la Recherche La Production Le Transport La Transformation et la Commercialisation des Hydrocarbures SPA v Statoil Natural Gas LLC (Statoil) [2014] EWHC 875. 
more attractive venue for arbitrations since the AA 1996, which has made challenges to and appeals from an arbitration award relatively rare. ${ }^{73}$

Despite the large numbers of London seated arbitrations (hundreds a year approximately), in 2015, only 31 reported challenges to arbitral awards were brought, which is a meaningful sign of the restrictive approach for challenging awards. ${ }^{74}$

\section{B. Challenging an Award Under the AA 1996}

\section{In General}

The finality of the process - the absence of a system for challenges or appeals - is often mentioned as an advantage of arbitration, and challenging awards have been seen as time-consuming and costly. ${ }^{75}$ Continuing the process which began in the Arbitration Act 1976, the AA 1996 codified additional restrictions on the factors in which a party is allowed to challenge an award in the English courts. ${ }^{76}$

The AA 1996 regulates three grounds on which a party may challenge a tribunal's awards in the English courts: 1-deficiency of substantive jurisdiction (section 67); 2-serious irregularity affecting the tribunal, proceedings or award (section 68); and 3-an appeal on a question of law (section 69). Also, sections 67, 68, 69 all expressly provide for appeals to the Court of Appeal, even though the guidelines behind the AA 1996 are to discourage such additional appeals. ${ }^{77}$

In this essay, the grounds on which a party may challenge a tribunal's awards are not examined in detail; however, these grounds are analysed partially within the scope of being an essential factor for London's attractiveness as the arbitral seat.

Section 67 and 68 are mandatory provisions of the AA 1996 and therefore cannot be eliminated by agreement of the parties; on the other hand, appeals under section 69 may be waived by agreement. ${ }^{78}$ Only the first two originate from the UNCITRAL Model Law ${ }^{79}$, but the third does not and instead symbolizes a delimited form of the

\footnotetext{
73 Hilary Heilbron, A Practical Guide to International Arbitration in London (1st edn., Informa Law 2008) 115.

74 Carter and Macpherson (n 68) 90.

75 David Wolfson and Susanna Charlwood 'Chapter 25: Challenges to Arbitration' in Julian D M Lew, Harris Bor, et al (eds) Arbitration in England, with Chapters on Scotland and Ireland (Kluwer Law International 2013) 527.

76 ibid.

77 AMEC Civil Engineering Ltd v Secretary of State for Transport [2005] EWCA Civ 291.

78 Section 4(1) and Section 1 of the AA 1996.

79 UNCITRAL Model Law on International Commercial Arbitration 1985, as amended in 2016, <https://uncitral.un.org/ sites/uncitral.un.org/files/media-documents/uncitral/en/19-09955_e_ebook.pdf $>$ (accessed 15.07.2021). However, the Model Law, article 34, provides for an arbitral award to be set aside in certain circumstances mainly different from those established by AA 1996, section 67 and 68, Kyriaki Noussia, 'The Arbitration Act 1996: Time for Reform' (2019) 2 Journal of Business Law 140, 145.
} 
wider right of appeal in the former Arbitration Act 1979 (AA 1979) ${ }^{80}$ to the AA $1996 .{ }^{81}$ Under section 69 of the AA 1996, a party may appeal on a question of law emerging in the proceedings. Section 69 stems from the AA 1979, as restrictively interpreted by the courts.$^{82}$ There is no counterpart to section 69 in the Model Law, and most of the leading arbitration jurisdictions do not support appeals on this basis. ${ }^{83}$

Section 69 of the Arbitration Act allows appeals to the court on a question of law arising out of an award made in the proceedings. Leave to appeal is only given with the permission of the court. Before granting permission to appeal, the court must be satisfied that ${ }^{84}$ : a-The determination of the issue will substantially affect the rights of one or more of the parties; $b$ - The question is one which the tribunal was asked to determine; c-(i) The decision was obviously wrong or (ii) that the question is one of general public importance and the decision is at least open to some doubt; $\mathrm{d}$-It is just and proper in all the circumstances for the court to determine the question despite the parties' agreement to arbitrate.

In this regard, the ground of challenge, which is prominent and focuses on the attractiveness of London as a favourable hub, is under section 69, an appeal on a question of law. Since many different countries adopted the Model law (rules) regarding challenging an award, AA 1996 section 69 creates a different preference for parties in arbitration and makes London attractive as the arbitral seat. In other words, London gives commercial parties the prospect of appealing an arbitral decision on the point of law. It is clear that the biggest factors behind London's preference among other seats proves to be the English courts' legislative framework and support of arbitration. ${ }^{85}$ On the other hand, section 69 creates an uncommon aspect and provides a route to appeal that is currently unavailable at other popular top seats.

\section{Some Discussions Regarding Section 69: The Delicate Balance Between Arbitration and the Courts}

Justice is an indivisible part of any civilised democratic society, and the state has overall responsibility to guarantee that justice is served both in private and public

80 Chapter 42, section 1 and 2, <http://www.legislation.gov.uk/ukpga/1979/42/pdfs/ukpga_19790042_en.pdf> (accessed 15.07.2021).

81 Wolfson and Charlwood (n 75) 561

82 Pioneer Shipping Ltd v BTP Tioxide Ltd (The Nema) (No 2) [1982] AC 724 (HL). Whilst section 69 of the AA 1996 is presumably not to be seen as a exact codification of the pioneering judicial guideliness, cases pre-existing the AA 1996 regarding appeals on questions of law persist to be relevant: CMA CGM SA v Beteiligungs-Kommanditgesellschaft MS 'Northern Pioneer'Schiffahrtsgesellschaft mBH \& Co (The Northern Pioneer) [2002] EWCA Civ 1878.

83 Wolfson and Charlwood (n 75) 543.

84 Section 69(3) AA 1996.

85 See Zuhair Farouki, 'Section 69 of the English Arbitration Act: London's discrete edge in its quest to become the top arbitration seat' Jus Mundi Blog, May 17 2021, <https://blog.jusmundi.com/section-69-of-the-english-arbitrationact-londons-discrete-edge-in-its-quest-to-become-the-top-arbitration-seat/?utm_source=rss\&utm_medium=rss\&utm campaign=section-69-of-the-english-arbitration-act-londons-discrete-edge-in-its-quest-to-become-the-top-arbitrationseat> (accessed 15.07.2021). 
tribunals. So, for justice to be fulfilled, the courts should not hesitate to intervene reasonably when necessary. ${ }^{86}$

The advancement of international arbitration law has been remarkable through an evident inclination to restrict the possible court interferences during an arbitration. On the other hand, it is progressively understood in the international arbitration community that the interference of the courts is not necessarily troublesome for the arbitration. It may even be supportive for the sake of efficiency and fairness in the arbitral process. ${ }^{87}$ However, it is not simple to balance the need for finality in the arbitral process and the broader public interest of judicial control, if only to protect the harmony of decisions and uniformity of the application of the law. ${ }^{88}$

It should also be noted that even though section 69 appeals in particular are very unlikely to succeed, section 69 applications are used as a prominent means by losing parties. Despite having minimal prospects of success, losing parties expect they have an opportunity to cause substantial delays and costs on their adversaries. Thus, losing parties can abuse this mechanism to reach a settlement or some other advantage for their benefit. ${ }^{89}$

In the course of the drafting of the AA 1996, there were proposals for the abolition of the right to appeal on a question of law, as it was regarded to represent an invasion by the courts on the independence of the arbitration process to which the parties had settled. ${ }^{90}$ However, the Departmental Advisory Committee on Arbitration (DAC) considered that a limited right of appeal on a question of law provides a convenient balance between the parties' decision to arbitrate rather than litigate on the one hand; and the necessity to assure that tribunals were accurately utilizing English law and that English courts could maintain to improve English law through arbitration appeals on the other. ${ }^{91}$ The 2007 Report of the Steering Committee created by the Commercial Court Users Committee, reviewing the workings of the AA 1996 through a survey of lawyers, arbitrators, parties and institutions, indicated that $60 \%$ were in favour of maintaining the right to appeal on a point of law as presented in section $69 .^{92}$

\footnotetext{
86 Lord Saville, 'The Denning Lecture 1995: Arbitration and the courts' (1995) 61 Arbitration 157.

87 Claude Reymond, 'The Channel Tunnel Case and the Law of International Arbitration' (1993) 109 LQR 337, 341; Hakeem Olalekan Seriki, Judicial Involvement and Intervention in Arbitration Proceedings After the Arbitration Act 1996, PhD Thesis, (Wales Cardiff, 2002) 3, 29, 60, 396 (emphasizing being 'supportive' rather than 'intrusive').

88 Nigel Blackaby, Constantine Partasides, Alan Redfern, J Martin Hunter, Redfern and Hunter on International Arbitration $\left(6^{\text {th }}\right.$ edn, OUP 2015) 592.

89 Jan Paulsson, 'Arbitration-Friendliness: Promises of Principle and Realities of Practice' (2007) 23/3 Arbitration International $477,489$.

90 R Holmes, M O’Reilly, ‘Appeals from Arbitral Awards: Should Section 69 be Repealed?' (2003) 69(1) Arbitration 1, 9; M Needham, 'Appeal on a Point of Law Arising out of an Award (1999) 65(3) Arbitration 205, 210-211.

91 DAC Report (n 72) paras 284-287.

92 Bruce Harris, 'Report on the Arbitration Act 1996' (2007) 23(3) Arbitration International 437; Paulsson (n 89) 491.
} 
The wording of the AA 1996 identifies limits on each of these grounds of challenge. Furthermore, the English courts have tended to approach the express requirements of the AA 1996 moderately, conforming with their general guidelines of non-interference in the arbitral process. ${ }^{93}$ As a consequence, challenges to arbitral awards are exceptionally successful. ${ }^{94}$ Nevertheless, the AA 1996 provides a resolute structure for the challenge where the arbitral process is endangered with serious concerns.

In this direction, in the recent case Alegrow S.A. v Yayla Agro Gida San ve Nak $A S^{95}$, even after leave to appeal had been granted, it was clear to see the court's reluctance to overturn arbitral awards. In this decision, it was emphasised that the English court should strive to uphold arbitration awards. ${ }^{96}$ In order to comply with this principle, the court should read an arbitration award in a reasonable and commercial way, that there will be no substantial fault that can be found. Thus, it should not approach awards "with a meticulous legal eye endeavouring to pick holes, inconsistencies and faults in awards and with the object of upsetting or frustrating the process of arbitration." 97 In cases of uncertainty, courts should construe the award in such a way as to make it valid rather than invalid..$^{98}$

Similarly, in Tricon Energy Ltd v MTM Trading LLC, ${ }^{99}$ English courts again showed their pro-arbitration approach by demonstrating a reluctance to interfere even after the permission to leave. In this case, the court exercised its supervisory role to remedy errors of law regarding a claim for demurrage. The charterers disputed that the demurrage claimed by the owners was due to the principal basis that the demurrage claim had not attached all necessary supporting documents as required by clause 38 of the charterparty terms, and specifically that the bills of lading had not been provided. As a consequence of these documents not being submitted, the charterers argued that they could not determine whether the claim was well-founded, and the demurrage claim had since become time-barred. ${ }^{100}$ The charterers appealed pursuant to section 69 of the Arbitration Act 1996 in respect of the following question of law

93 Wolfson and Charlwood (n 75) 561; Carter and Macpherson (n 68) 91; Neil Andrews, The Modern Civil Process, Judicial and Alternative Forms of Dispute Resolution in England (Mohr Siebeck 2008) 260.

94 There are recent examples of rare success achieved by the parties in challenging arbitral awards on points of law, Tricon Energy Ltd v MTM Trading LLC [2020] EWHC 700 (Comm) (the court held that the tribunal had been wrong to conclude that the claim was not time-barred under the provisions of the relevant contract. Contrary to the findings of the tribunal, the original claim was filed without all the necessary documents and was therefore defective. As the limitation period had subsequently passed, the claim became time-barred), Alegrow S.A. v Yayla Agro Gida San ve Nak AS [2020] EWHC 1845 (Comm), and CVLC Three Carrier Corp v Arab Maritime Petroleum Transport Co [2021] EWHC 551 (Comm).

95 Alegrow S.A. v Yayla Agro Gida San ve Nak AS [2020] EWHC 1845 (Comm).

96 Referring MRI Trading AG v Erdenet Mining Corporation LLC [2013] 1 Lloyd's Rep 638 in Alegrow S.A. v Yayla Agro Gida San ve Nak AS [2020] EWHC 1845 (Comm) at [48].

97 ibid.

98 ibid.

99 Tricon Energy Ltd v MTM Trading LLC [2020] EWHC 700 (Comm).

100 Tricon Energy Ltd v MTM Trading LLC [2020] EWHC 700 (Comm) at [22]. 
arising out of the award: "Where a charterparty requires demurrage to be calculated by reference to the bill of lading quantities and contains a demurrage time bar which requires the provision of all supporting documents, will a claim for demurrage be time-barred if the vessel owner fails to provide copies of the bills of lading?". ${ }^{101}$ The Court decided that there was a requirement to provide the bills of lading with the claim in accordance with clause $38 .{ }^{102}$

Moreover, there is a considerable amount of English jurisprudence on the relevant provisions of the AA 1996, such that a party determining a challenge is comprehensively supported to evaluate its likely prospects of success. ${ }^{103}$

Section 69 of the AA 1996 has given a very restricted right of appeal of awards to the English courts on a point of law. ${ }^{104}$ Practitioners are inclined to like this protected nature of arbitration, but also the section 69 'balancing act' has been seen as being devoted redundantly for the sake of arbitral autonomy, impeding the progress of the common law and neglecting the exigence to guarantee the uniform application of English law. ${ }^{105}$ From this point of view, the common criticisms of a more permissive right of appeal - the need to protect privacy and confidentiality and party autonomy are considered to be exaggerated. ${ }^{106}$ In order to rebalance section 69 , it is recommended that the present provision that the question of law is of "general public importance" for decisions that are not "obviously wrong" should be shifted by the requirement that the question of "general doctrinal importance or of general importance to the industry concerned." 107

Overall, redressing the necessary balance is of serious importance: hardly any appeals endanger deadlocking the improvement of the common law. On the other hand, too many appeals jeopardize disaffecting users of arbitration from London. ${ }^{108}$ There are two fundamental points in favour of a more permissive section 69: 1-developing the common law, 2-securing the coherent practice of English law. There are five concerns regarding the principles of the Act against a more permissive section 69: 1-the necessity for finality in arbitration, 2-the privacy and confidentiality of arbitration, 3-the notion that English arbitration law is different from that of other jurisdictions and the UNCITRAL Model Law ${ }^{109}$ in allowing appeals for error of

\footnotetext{
101 Tricon Energy Ltd v MTM Trading LLC [2020] EWHC 700 (Comm) at [17].

102 Tricon Energy Ltd v MTM Trading LLC [2020] EWHC 700 (Comm) at [36].

103 Wolfson and Charlwood (n 75) 561.

104 Richard Liu, 'A Balancing Act: Section 69 of the Arbitration Act 1996' (2018) 21 (1) International Arbitration Law Review 18.

105 ibid.

106 ibid.

107 ibid.

108 ibid.

109 UNCITRAL Model Law (n 79).
} 
autonomy, 4-the economic need to maintain the desirability of the London seat of arbitration, and 5-party autonomy. ${ }^{110}$

Several prominent cases ${ }^{111}$ derived from arbitration after the 'Nema Guidelines'112 which recognized a restrictive interpretation of the Arbitration Act 1979 still remain under the AA 1996. ${ }^{113}$ This situation indicates that a restrictive appeal structure is not an obstruction to the common law's progress. ${ }^{114}$ In this regard, a more permissive section 69 would harm the core principles of arbitration and the leading position of London as an arbitral seat. This delicate balance provided by the AA 1996 should be protected in the same way.

\section{Conclusion}

There are various determinants that induce London to be the favourable seat: ease of travel, accommodation, hearing rooms, political stability, political and cultural neutrality, reliability and neutrality of the legal system, quality of local arbitrators, quality of the court system, convenient geographical location, telecommunication, airports, hotels, restaurants, and banks that function adequately.

On the other hand, the grounds for challenging an award have some severe implications on determining London as the arbitral seat. The consensual nature of international arbitration depends on some core principles like party autonomy, judicial non-intervention and finality of the arbitral awards. Nonetheless, the binding aspect of the arbitral award and its enforceability akin to that of final judgements of national courts necessitate some "balanced" degree of judicial supervision. ${ }^{115}$

English courts are firmly supportive of international arbitration, adhering to the principles of party autonomy and judicial non-interference preserved in the Act. ${ }^{116}$ Relatively few challenges have been made to London seated arbitral awards, which indicates the quality of arbitral tribunal's decisions. However, it is also possible to conceive that few challenges are an acknowledgement by parties that there is a low probability of succeeding in any challenge. ${ }^{117}$

110 Liu (n 104).

111 The Achilleas [2008] UKHL 48, [2009] 1 AC 61.

112 Originated from The Nema [1982] AC 724 (HL).

113 On the other hand, it is true that, there is a large extent decline in the applications for permission to appeal each year under section 69. There had been about 300 special cases each year prior to 1979, however in 2015 there were 58 applications for permission to appeal under section 69, with 19 of them being granted permission, Lord Thomas, 'Developing Commercial Law Through the Courts: Rebalancing the Relationship Between the Courts and Arbitration' Courts and Tribunals Judiciary 2016, paragraph 21, <https://www.judiciary.uk/wp-content/uploads/2016/03/lcj-speech-bailli-lecture-20160309. pdf $>$ (accessed 15.07.2021).

114 Liu (n 104) 19.

115 Hossein Abedian, 'Judicial Review of Arbitral Awards in International Arbitration-A Case for an Efficient System of Judicial Review' (2011) 28 (6) Journal of International Arbitration 533.

116 Speller and Feldner (n 47).

117 Carter and Macpherson, (n 68) 91. 
Most importantly, AA 1996 ensures a very sensitive balance between the arbitration parties' autonomy and the English courts' role as gatekeepers of justice to preserve the integrity of the arbitration. ${ }^{118}$ A restrictive appeal system does not harm the judicial non-intervention and party autonomy. On the contrary, it allows an effective and fair arbitral award to be reached. Besides this, this optional "opt-out" right to appeal mechanism, which is an essential factor of access to justice, can significantly reinforce parties' trust in the arbitral process by supporting overall legitimacy. ${ }^{119}$

The AA 1996's attitude towards providing a delicate balance between courts and arbitration promotes the preference of London as the arbitral seat. In addition, since the grounds for challenging an award under the AA 1996 (particularly regarding section 69) are distinct from other jurisdictions and UNCITRAL Model Law, the attractiveness of London as the arbitral seat has increased.

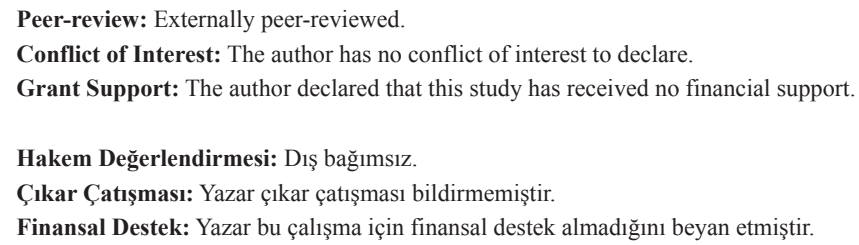

\section{Bibliography}

\section{Books}

Andrews N, The Modern Civil Process, Judicial and Alternative Forms of Dispute Resolution in England (Mohr Siebeck 2008)

Belohlavek A J, 'Seat of Arbitration and Supporting and Supervising Function of Courts' in Alexander Belohlavek, Nadezda Rozehnalova (eds), Interaction of Arbitration and Courts, Czech Yearbook of Arbitration, vol 5 (2015, Juris)

Blackaby N, Partasides C, Redfern A, Hunter J M, Redfern and Hunter on International Arbitration $\left(6^{\text {th }}\right.$ edn, OUP 2015)

Blake S, Browne J, Sime S, A Practical Approach to Alternative Dispute Resolution ( $5^{\text {th }}$ edn, OUP 2018)

Born G B, International Commercial Arbitration, (Kluwer Law International 2014)

Born G B, International Arbitration and Forum Selection Agreements: Drafting and Enforcing, (3th edn, Wolters Kluwer International 2010)

Greenberg S, Kee C, Weeramantry R, International Commercial Arbitration: An Asia-Pacific Perspective (CUP 2011)

Heilbron H, A Practical Guide to International Arbitration in London (1st edn., Informa Law 2008)

Karrer P A, Introduction to International Arbitration Practice (Kluwer Law International 2014)

118 Lew (n 12) 243; David St J Sutton, Judith Gill, Russell on Arbitration (24 ${ }^{\text {th }}$ edn, Sweet and Maxwell 2015) 6.

119 Noam Zamir, ‘Appeal in International Arbitration-An Efficient and Affordable Arbitral Appeal Mechanism' (2019) 35(1) Arbitration International 79, 86. 
Lalive P, 'On the Neutrality of the Arbitrator and of the Place of Arbitration', Swiss Essays on International Arbitration (1984), 30, 31, https://www.lalive.law/data/publications/43_-_On_ the_Neutrality_of_the_Arbitrator_and_of_the_Place_of_Arbitration_Recueil_de_travaux_ suisses_sur_l'arbitrage_international.pdf

Lew J, 'London' in Michael Ostrove, Cladia Salomon, Bette Shifman (eds), Choice of Venue in International Arbitration (OUP 2014)

Petrochilos G, Procedural Law in International Arbitration (OUP 2004)

Seriki H O, Judicial Involvement and Intervention in Arbitration Proceedings After the Arbitration Act 1996, PhD Thesis, (Wales Cardiff, 2002)

Sutton D S J, Gill J, Russell on Arbitration (24 ${ }^{\text {th }}$ edn, Sweet and Maxwell 2015)

Turner P, Mohtashami R, A Guide to the LCIA Arbitration Rules (OUP 2009)

Waincymer J, Procedure and Evidence in International Arbitration, (Kluwer Law International 2012)

Wolfson D, Charlwood S, 'Chapter 25: Challenges to Arbitration' in Julian D M Lew, Harris Bor, et al (eds) Arbitration in England, with Chapters on Scotland and Ireland (Kluwer Law International 2013)

\section{Articles}

Abedian H, 'Judicial Review of Arbitral Awards in International Arbitration-A Case for an Efficient System of Judicial Review' (2011) 28 (6) Journal of International Arbitration 533

Carter J, Macpherson C, 'Arbitral Awards-Challenging to Challenge' (2016) 19 (4) International Arbitration Law Review 89

Gelander J L, 'Judicial Review of International Arbitral Awards: Preserving Independence in International Commercial Arbitrations' (1997) 80 Marquette Law Review 625

Giovannini T, 'The Making and Enforcement of Arbitral Award: What are the Grounds on Which Awards Are Most Often Set Aside?' (2001) 1 Business Law International 115

Harris B, 'Report on the Arbitration Act 1996' (2007) 23(3) Arbitration International 437

Hill J, 'Determining the Seat of an International Arbitration: Party Autonomy and the Interpretation of Arbitration Agreements' (2014) 63 Int Comp Law Q 517

Holmes R, O’Reilly M, ‘Appeals from Arbitral Awards: Should Section 69 be Repealed?' (2003) 69(1) Arbitration 1

Liu R, 'A Balancing Act: Section 69 of the Arbitration Act 1996' (2018) 21 (1) International Arbitration Law Review 18

Mcllwrath M, 'An Unamicable Separation: Brexit Consequences for London as a Premier Seat of International Dispute Resolution in Europe' (2016) 33 (7) Journal of International Arbitration 451

Needham M, 'Appeal on a Point of Law Arising out of an Award' (1999) 65(3) Arbitration 205

Noussia K, ‘The Arbitration Act 1996: Time for Reform' (2019) 2 Journal of Business Law 140

Paulsson J, ‘Arbitration-Friendliness: Promises of Principle and Realities of Practice', (2007) 23/3 Arbitration International 477

Saville L, 'The Denning Lecture 1995: Arbitration and the courts' (1995) 61 Arbitration 157

Seriki H, 'Enforcing Annulled Arbitral Awards: Can the Unruly Horse Be Tamed?' (2018) 8 Journal of Business Law 679 
The UK Departmental Advisory Committee, 'DAC Report', The 1996 DAC Report on the English Arbitration Bill: The Last Part, (1999) 15(4) Arbitration International 413

Vial G, 'Influence of the Arbitral Seat in the Outcome of an International Commercial Arbitration' (2017) 50(2) International Lawyer 329

Vial G, Blavi F, 'New Ideas for the Old Expectation of Becoming an Attractive Arbitral Seat' (2016) 25 Transnational Law \& Contemporary Problems 279

Walker J, 'The London Principles and Their Impact on Law Reform' (2018) 84 (2) Arbitration 174

Zamir N, 'Appeal in International Arbitration-An Efficient and Affordable Arbitral Appeal Mechanism' (2019) 35(1) Arbitration International 79

\section{News, and Analysis}

Capper P, Sabharwal D, Connellan C, 'When is the 'Venue' of an Arbitration its 'Seat'?, Kluwer Arbitration Blog (November 25, 2009), http://arbitrationblog.kluwerarbitration.com/2009/11/25/ when-is-the-venue-of-an-arbitration-its-seat/

Farouki Z, 'Section 69 of the English Arbitration Act: London's discrete edge in its quest to become the top arbitration seat' Jus Mundi Blog, May 17 2021, <https://blog.jusmundi.com/ section-69-of-the-english-arbitration-act-londons-discrete-edge-in-its-quest-to-become-thetop-arbitration-seat/?utm_source=rss\&utm_medium $=$ rss\&utm_campaign=section-69-of-theenglish-arbitration-act-londons-discrete-edge-in-its-quest-to-become-the-top-arbitration-seat>

Hesse D, 'The Seat of Arbitration is Important. It's That Simple.', Kluwer Arbitration Blog, (June 10, 2018), http://arbitrationblog.kluwerarbitration.com/2018/06/10/seat-arbitration-importantsimple/

Jain S, 'UK: Why London Continues to be an Attractive Seat for International Arbitration Post-Brexit' Mondaq, 23 June 2021, https://www.mondaq.com/uk/arbitration-dispute-resolution/1082072/ why-london-continues-to-be-an-attractive-seat-for-international-arbitration-post-brexit

Kirtley W, The Importance of the Seat of Arbitration, International Arbitration Attorney Network (February 8, 2016), <https://www.international-arbitration-attorney.com/importance-seat-arbitration/>

Speller D, Feldner M, 'The International Arbitration Review: United Kingdom-England and Wales', edition 12, (July 2021) < https://thelawreviews.co.uk/title/the-international-arbitrationreview/united-kingdom-england--wales >

Lord Thomas, 'Developing Commercial Law Through the Courts: Rebalancing the Relationship Between the Courts and Arbitration' Courts and Tribunals Judiciary 2016, paragraph 21, https:// www.judiciary.uk/wp-content/uploads/2016/03/lcj-speech-bailli-lecture-20160309.pdf

Williams J, Lal H, Hornshaw R, 'Arbitration procedures and practice in the UK (England and Wales): overview' $<$ https://uk.practicallaw.thomsonreuters.com/4-502-1378?transitionType=D efault\&contextData $=($ sc.Default $) \&$ firstPage $=$ true $>$

2018 Queen Mary University of London, White \& Case International Arbitration Survey: The Evolution of International Arbitration, <http://www.arbitration.qmul.ac.uk/media/arbitration/ docs/2018-International-Arbitration-Survey---The-Evolution-of-International-Arbitration-(2). PDF>

2021 International Arbitration Survey: Adapting arbitration to a changing world, <http://www. arbitration.qmul.ac.uk/media/arbitration/docs/LON0320037-QMUL-International-ArbitrationSurvey-2021_19_WEB.pdf> 


\section{Cases}

The Achilleas [2008] UKHL 48, [2009] 1 AC 61

Allianz SpA and Others $v$ West Tankers Inc [2009] EUECJ C-185/07

AMEC Civil Engineering Ltd v Secretary of State for Transport [2005] EWCA Civ 291

Bandwidth Shipping Corporation Intaari (the 'Magdelena Oldendorff') [2007] EWCA Civ 998, [2008] 1 All ER (Comm) 1015, [2008] 1 Lloyd's Rep 7

Braes of Doune Wind Farm (Scotland) Ltd v Alfred McAlpine Business Services Ltd [2008] 2 All ER (Comm) 493

$C v D$ [2008] Bus LR 843

CMACGMSA v Beteiligungs-Kommanditgesellschaft MS 'Northern Pioneer'Schiffahrtsgesellschaft $m B H \& C o$ (The Northern Pioneer) [2002] EWCA Civ 1878

Essar Oilfields Services Ltd v Norscot Rig Management PVT Ltd [2016] EWHC 2361 (Comm)

HC Trading Malta Ltd v Tradeland Commodities SL [2016] EWHC 1279 (Comm)

Itochu Corporation v Johann MK Blumenthal GMBH \& Co KG \&Anr [2012] EWCA Civ 996

La Société pour la Recherche La Production Le Transport La Transformation et la Commercialisation des Hydrocarbures SPA v Statoil Natural Gas LLC (Statoil) [2014] EWHC 875

Pioneer Shipping Ltd v BTP Tioxide Ltd (The Nema) (No 2) [1982] AC 724 (HL)

Shashoua and ors $v$ Sharma [2009] EWHC 957 (Comm)

Gerald Metals SA v The Trustees of the Timis Trust and others [2016] EWHC 2327

Tricon Energy Ltd v MTM Trading LLC [2020] EWHC 700 (Comm)

Alegrow S.A. v Yayla Agro Gida San ve Nak AS [2020] EWHC 1845 (Comm)

CVLC Three Carrier Corp v Arab Maritime Petroleum Transport Co [2021] EWHC 551 (Comm) 